\title{
Infusions of Herbal Blends as Promising Sources of Phenolic Compounds and Bioactive Properties
}

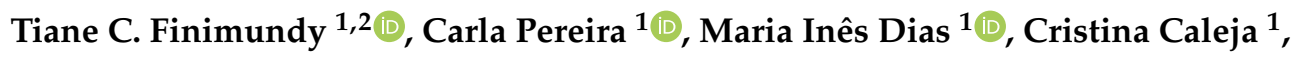

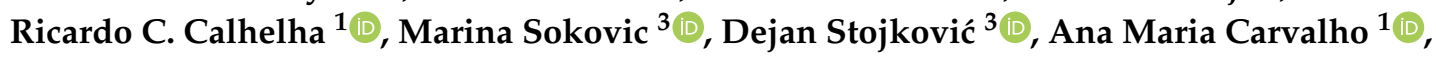 \\ Eduardo Rosa ${ }^{2}$, Lillian Barros ${ }^{1, *}$ (D) and Isabel C. F. R. Ferreira $1, *$ (D) \\ 1 Centro de Investigação de Montanha (CIMO), Instituto Politécnico de Bragança, Campus de Santa Apolónia, \\ 5300-253 Bragança, Portugal; tiane@ipb.pt (T.C.F.); carlap@ipb.pt (C.P.); maria.ines@ipb.pt (M.I.D.); \\ ccaleja@ipb.pt (C.C.); calhelha@ipb.pt (R.C.C.); anacarv@ipb.pt (A.M.C.) \\ 2 CITAB - University of Trás-os-Montes and Alto Douro (UTAD), Department of Agronomy, \\ 5001-801 Vila Real, Portugal; erosa@utad.pt \\ 3 Institute for Biological Research "Siniša Stanković", National Institute of Republic of Serbia, \\ University of Belgrade, 11000 Belgrade, Serbia; mris@ibiss.bg.ac.rs (M.S.); dejanbio@ibiss.bg.ac.rs (D.S.) \\ * Correspondence: lillian@ipb.pt (L.B.); iferreira@ipb.pt (I.C.F.R.F.); \\ Tel.: +351-273-330901 (L.B.); +351-273-303219 (I.C.F.R.F.)
}

Academic Editor: Derek J. McPhee

Received: 17 April 2020; Accepted: 28 April 2020; Published: 4 May 2020

\begin{abstract}
Several plants have been used for medicinal applications and have been traditionally consumed as decoctions and infusions. Although some herbs are used alone as a beverage, they are often blended in mixtures to maximize their effects. Herein, the nutritional characterization of six infusions from herbal blends was evaluated using the official methods of analysis (AOAC international). A further characterization of the individual phenolic profile was also performed by HPLC-DAD/ESI-MSn, and finally bioactive potential was determined by evaluating the antioxidant, cytotoxic, anti-inflammatory, and antimicrobial activities of each blend. The wide variety of plants in each sample led to variability in the results for all analyzed parameters. However, blends containing $15 \%$ Laurus nobilis $\mathrm{L}$. and 15\% Juglan regia $\mathrm{L}$. in their composition showed higher sugar content and energy contribution; higher concentration of phenolic compounds (phenolic acids and flavonoids); greater antioxidant, cytotoxic, and anti-inflammatory capacity; and also better antimicrobial effects against all the tested bacterial and fungal strains. Further studies will be necessary to evaluate the real synergistic effects that these two species show in the presence of other plants, and to evaluate their potential for application in various food, pharmaceutical, and nutraceutical products as infusion preparations.
\end{abstract}

Keywords: herbal blends; nutritional profile; phenolic compounds; HPLC-DAD/ESI-MSn; bioactive properties

\section{Introduction}

The search for new, safer, and sustainable high-added-value compounds relies to a certain degree on the continuous study of traditionally used medicinal plants [1]. These plants have been used since ancient times for their countless benefits, being associated with health-promoting properties $[2,3]$. Conventionally prepared as an infusion, decoction, or by maceration (also used for culinary purposes due to their fragrance and flavor), these herbs can be blended in different combinations of leaves, roots, barks, stems, and flowers, among other plant materials [4]. One of the botanical families containing an enormous range of species most commonly consumed as herbal tea is the Lamiaceae family, which brings together an enormous range of plants (e.g., Rosmarinus officinalis L. and Thymus mastichina L.) 
that have several recognized bioactive properties and beneficial health effects [5-7]. Another widely used botanical family is the Asteraceae family, comprising plants such as Calendula arvensis L. and Chamaemelum nobile L., which have been extensively studied [8-10] and also present a wide range of bioactive properties. The species I this family are of great commercial and economic value, with potential to be applied in the food and pharmaceutical industries. There are other plant families that are still underexplored, despite showing promising potential to be used as sources of high-added-value compounds, such as Lauraceae (e.g., Laurus nobilis L.), Oleaceae (e.g., Olea europaea L.), Vitaceae (e.g., Vitis vinifera L.), Apiaceae (e.g., Foeniculum vulgare Mill.), and Juglandaceae (e.g., Juglans regia L.) families, among others [11-15]. The demand of today's consumers for foods marketed as healthier and natural has led the food industry to seek new formulation products to meet their high expectations [16], such as blending herbs from different botanical families. These mixtures can present additive and synergistic effects and increase the content of compounds of interest, improving the nutritional value of these products, and also by acting as sources of functional ingredients to be incorporated into food products $[16,17]$. In this sense, the present work was performed to chemically characterize six herbal blends (complete description in Table 1), namely relating to their profiles in individual sugars and phenolic compounds. Moreover, it also aimed to evaluate their antioxidant, cytotoxic, anti-inflammatory, and antimicrobial properties, comparing these results with previously reported data on the individual plants, allowing a better understanding of the eventual synergistic effects existing in these innovative mixtures.

Table 1. Description and morphological characteristics of the six herbal blends provided by Ervital ${ }^{\circledR}$ company.

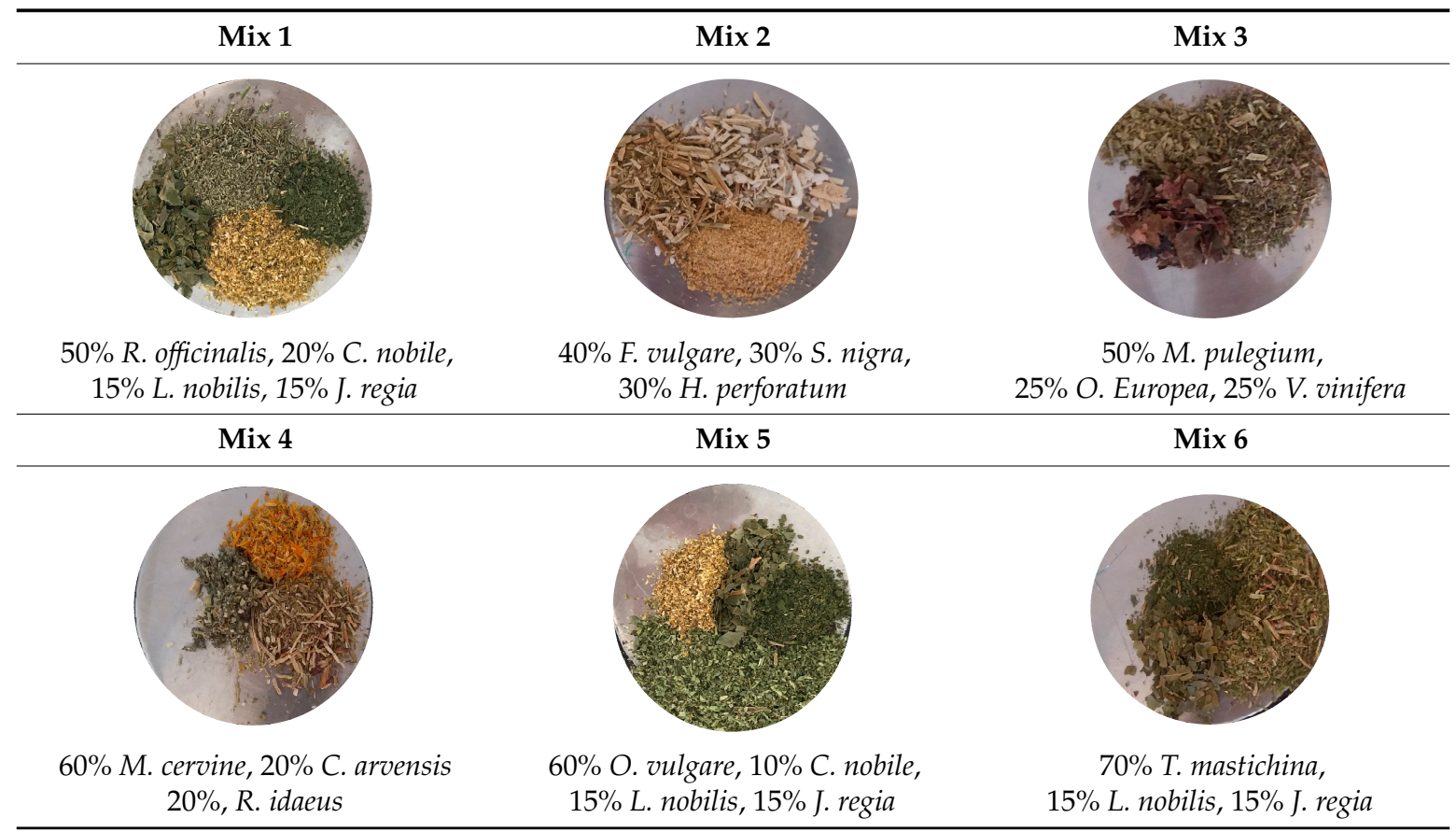

The morphological characteristics of the six herbal blends were flowering aerial parts of Foeniculum vulgare Mill., Hypericum perforatum L., Mentha cervina L., Mentha pulegium L., Origanum vulgare subs. virens Hoffm. and Link, and Thymus mastichina L; flower heads of Calendula arvensis L., Chamaemelum nobile (L.) All., and Sambucus nigra L.; and leaves of Juglans regia L., Laurus nobilis L., Olea europaea L., Rosmarinus officinalis L., Rubus idaeus L., and Vitis vinifera L.

\section{Results and Discussion}

\subsection{Nutritional Analysis and Sugar Composition}

The total contents of fat, ash, and proteins in the infused blend were, as expected (and confirmed in previous studies by Caleja et al. [18]), below the limits of detection, and consequently below the limits of quantification of the equipment and protocols used to perform these analyses. Therefore, 
assuming total sugars as total carbohydrates, the calculation of energy was performed according to the following equation: energy (cal) $=4 \times$ (mg carbohydrates). Data on the free sugar content and energy contribution of the six infusions are shown in Table 2.

Table 2. Free sugar and carbohydrate contents and energy contributions of the six infused blends $($ mean $\pm \mathrm{SD})$.

\begin{tabular}{|c|c|c|c|c|c|c|}
\hline & $\operatorname{Mix} 1$ & $\operatorname{Mix} 2$ & $\operatorname{Mix} 3$ & $\operatorname{Mix} 4$ & Mix 5 & $\operatorname{Mix} 6$ \\
\hline \multicolumn{7}{|c|}{ Free sugars $(\mathrm{mg} / 100 \mathrm{~mL})$} \\
\hline Fructose & $22.1 \pm 0.4^{b}$ & $13.3 \pm 0.6^{c}$ & $9.1 \pm 0.4^{\mathrm{d}}$ & $13.3 \pm 0.3^{c}$ & $30 \pm 1^{\mathrm{a}}$ & nd \\
\hline Glucose & $12.6 \pm 0.5^{c}$ & $17.1 \pm 0.7^{\mathrm{a}}$ & nd & $3.5 \pm 0.1^{\mathrm{d}}$ & $15.3 \pm 0.5^{b}$ & nd \\
\hline Sucrose ${ }^{*}$ & nd & nd & nd & nd & $29 \pm 1$ & $6.5 \pm 0.1$ \\
\hline Total sugars & $35 \pm 1^{b}$ & $30 \pm 1^{c}$ & $9.1 \pm 0.4^{\mathrm{e}}$ & $16.8 \pm 0.1^{\mathrm{d}}$ & $75 \pm 2^{a}$ & $6.5 \pm 0.1^{\mathrm{f}}$ \\
\hline Energy (cal/100 mL) & $139 \pm 4^{b}$ & $122 \pm 5^{c}$ & $36 \pm 1^{\mathrm{e}}$ & $67.2 \pm 0.6^{d}$ & $298 \pm 6^{a}$ & $25.8 \pm 0.3^{f}$ \\
\hline
\end{tabular}

Protein, ash, and fat contents were zero; results expressed as medium value \pm standard deviation (SD); nd = not detected. Mix 1: 50\% R. officinalis, 20\% C. nobile, $15 \%$ L. nobilis, 15\% J. regia. Mix 2: $40 \%$ F. vulgare, 30\% S. nigra, 30\% H. perforatum. Mix 3: 50\% M. pulegium, 25\% O. europaea, 25\% V. vinifera. Mix 4: $60 \%$ M. cervine, $20 \%$ C. arvensis, $20 \%$ R. idaeus. Mix 5: $60 \%$ O. vulgare, $10 \%$ C. nobile, $15 \%$ L. nobilis, $15 \%$ J. regia. Mix 6: $70 \%$ T. mastichina, $15 \%$ L. nobilis, $15 \%$ J. regia. The statistical treatment was performed by comparing the mixtures; therefore, in each row different letters indicate statistically significant differences $(p<0.05) .{ }^{*}$ For sucrose individually, the statistical analysis was performed using the Student's $t$-test $p$-value, $<0.001$.

The qualitative and quantitative profiles of individual sugars in the six blends were quite different, with mix 1, mix 2, and mix 4 presenting fructose and glucose, and mix 3 and mix 6 only revealing the presence of fructose and sucrose, respectively. On the other hand, mix 5 was the only blend presenting these three sugars, also showing the highest concentration of total sugars $(75 \pm 2 \mathrm{mg} / 100 \mathrm{~mL})$. Given the fact that this was the only blend containing O. vulgare and that it was its main constituent $(60 \%)$, its high sugar content can be possibly ascribed to this species. In a previous study performed by Pereira et al. [19], a sample of O. vulgare, in which the subspecies was not identified, revealed a total sugar content of $19 \pm 1 \mathrm{~g} / 100 \mathrm{~g}$ of dry plant, also revealing the presence of trehalose; however, in refenced study the infusion was not assessed, so the results are not comparable to the ones presented herein. In mix 1, the most abundant species was R. officinalis (50\%). For this herbal infusion, no sugars were detected in a previous study [19], which suggests that the sugar content of the mixture is due to the contributions of the other plants (C. nobile, L. nobilis, and J. regia). Indeed, Pereira et al. [19] reported a total sugar content of $15.0 \pm 0.2 \mathrm{mg} / 100 \mathrm{~mL}$ for the $C$. nobile infusion and $10.46 \pm 0.02 \mathrm{~g} / 100 \mathrm{~g}$ of dried sample (not directly comparable) for L. nobilis. Regarding mix 2 , in a previous study, F. vulgare infusion had a total sugar amount of $15.0 \pm 0.9 \mathrm{mg} / 100 \mathrm{~mL}$ [19], lower than the one found for this mixture, which was composed of $40 \%$ of this plant. This suggests that the remaining plants in the blend had a higher contribution. Given the fact that S. nigra and H. perforatum were not present in the other herbal blends, this possibility was not discussed further.

Consequently, mix 5 also presented the highest energetic contribution $(298 \pm 6 \mathrm{cal} / 100 \mathrm{~mL})$, followed by mix $1(139 \pm 4 \mathrm{cal} / 100 \mathrm{~mL})$ and $\mathrm{mix} 2(122 \pm 5 \mathrm{cal} / 100 \mathrm{~mL})$. As far as we know, there are no reports on these plants' infusion energy values, except for C. nobile, F. vulgare, M. pulegium, R. officinalis, and T. mastichina individually $(59.8 \pm 0.9,60 \pm 3,47.4 \pm 0.85, \sim 0$, and $34 \pm 2 \mathrm{cal} / 100 \mathrm{~mL}$, respectively) [19].

\subsection{Phenolic Compounds Characterization}

The retention time (Rt), wavelengths of maximum absorption in the visible region $\left(\lambda_{\max }\right)$, mass spectral data, and tentative identification of the phenolic compounds in the six blends are presented in Table 3. The quantification results ( $\mathrm{mg} / \mathrm{g}$ extract) of the phenolic compounds present in the six blends are presented in Table 4. Fifty-two phenolic compounds were found in the six blends, among which twenty-eight were phenolic acids, twenty-three were flavonoids, and two were unknown compounds. All the plants in these blends were previously studied for their phenolic composition profiles. As such, 
the identification of all the compounds was performed using the bibliographic references described in the footnotes of Table 3. Twenty phenolic compounds were detected in mix 1, with peak 30 representing the main compound (luteolin-3'-O-glucuronide, $4.6 \pm 0.1 \mathrm{mg} / \mathrm{g}$ extract). Additionally, this mixture had a high percentage of $R$. officinalis; its main phenolic compounds were not the ones described for the aqueous form of this plant (infusions and decoction) [20] or for hydroethanolic extracts [6], namely rosmarinic acid and its derivatives. In the case of the mixture, C. nobile [8] and L. nobilis [21] seemed to have a greater influence on the phenolic composition, with luteolin-O-glucuronide being the major peak detected. Tuberonic acid hexoside (peak 7, $[\mathrm{M}-\mathrm{H}]^{-}$at $m / z$ 387) showed fragments at $m / z 207$, which corresponds to the aglycone after loss of hexose $[\mathrm{M}-\mathrm{H}-162]^{-}$, and has been previously described in other plants of the Lamiaceae family [22]. Nine compounds were tentatively identified in mix 2. This blend comprised F. vulgare, S. nigra, and H. perforatum, and previous studies on the individual phenolic profiles of these plants revealed quercetin glycosylated derivatives as the main compounds $[14,15,23]$, which is in accordance with the results obtained herein, showing peak 20 (quercetin-3-O-rutinoside, $[\mathrm{M}-\mathrm{H}]^{-}$at $\left.\mathrm{m} / \mathrm{z} 609\right)$ as the main compound $(31.1 \pm 1.3 \mathrm{mg} / \mathrm{g}$ extract). In mix 3 , eight compounds were tentatively identified, with oleuropein (peak 44, $[\mathrm{M}-\mathrm{H}]^{-}$at $m / z 539$ ) being the major compound found. This is probably due to the $25 \%$ content of $M$. pulegium, since these secoiridoid-type compounds are very common and abundant in the Oleaceae family [12,24]. Thirteen phenolic compounds were tentatively identified in mix 4, with rosmarinic acid being the major compound $(13.03 \pm 0.05 \mathrm{mg} / \mathrm{g}$ extract). Taking into account the high amount of $M$. cervina in the mixture, and considering a study describing rosmarinic acid as the major compound found in this plant [25], it is possible to state that M. cervina has a great influence on the phenolic composition of this blend. Regarding mix 5, twelve phenolic compounds were tentatively identified, and as in the previous mixture, rosmarinic acid was the major compound $(33.9 \pm 0.1 \mathrm{mg} / \mathrm{g}$ of extract). Likewise, the high percentage $(60 \%)$ of 0 . vulgare should explain this result, since Origanum genus plants are characterized by containing rosmarinic acid and its derivatives as the main compounds [26]. Finally, ten compounds were tentatively identified in mix 6, with peak $31\left([\mathrm{M}-\mathrm{H}]^{-}\right.$at $\left.m / z 447\right)$ being tentatively identified as kaempferol-O-hexoside, the major compound in this mix ( $35 \pm 1 \mathrm{mg} / \mathrm{g}$ extract). This was an expected result, since the presence of this compound was described in the individual assessment of the phenolic composition of T. mastichina [6], L. nobilis [21], and J. regia [27].

Table 3. Retention time (Rt), wavelengths of maximum absorption in the visible region $\left(\lambda_{\max }\right)$, mass spectral data, and identification of phenolic compounds in the six infused blends.

\begin{tabular}{|c|c|c|c|c|c|}
\hline Peak & $\begin{array}{c}\mathrm{Rt} \\
(\mathrm{min})\end{array}$ & $\begin{array}{c}\lambda \max \\
(\mathrm{nm})\end{array}$ & $\begin{array}{c}{[\mathbf{M}-\mathbf{H}]} \\
m / z\end{array}$ & MS $^{2}$ & Tentative Identification \\
\hline 1 & 4.47 & 328 & 311 & $179(100), 149(83), 135(72)$ & Caftaric acid \\
\hline 2 & 4.58 & 324 & 353 & $191(100), 179(45), 135(7)$ & 3-O-Caffeoylquinic acid \\
\hline 4 & 6.45 & 319 & 353 & 191(20),179(50),173(100),135(3) & 4-O-Caffeoylquinic acid \\
\hline 5 & 6.48 & 267 & 305 & $226(13), 225(100), 175(2), 97(44)$ & $(+)-$ Gallocatechin \\
\hline 6 & 6.81 & 319 & 353 & $191(100), 179(24), 173(37)$ & 5-O-Caffeoylquinic acid \\
\hline 9 & 9.59 & 320 & 179 & $135(100)$ & Caffeic acid \\
\hline 10 & 9.8 & 319 & 313 & $197(100)$ & Salvianolic acid F \\
\hline 11 & 10.74 & 284 & 449 & $287(100)$ & Eriodictyol-O-hexoside isomer 1 \\
\hline 12 & 11.71 & 340 & 337 & 191(3),173(100),163(43),155(12),119(12) & 4- $p$-Coumaroylquinic acid \\
\hline 13 & 12.2 & 284 & 449 & $287(100)$ & Eriodictyol-O-hexoside isomer 2 \\
\hline 14 & 13.33 & 339 & 637 & $285(100)$ & Luteolin-O-di-glucuronide \\
\hline 19 & 15.1 & 333 & 521 & $359(50), 197(20), 179(37), 161(100)$ & Rosmarinic acid hexoside \\
\hline 20 & 15.31 & 334 & 609 & $301(100)$ & Quercetin-3-O-rutinoside \\
\hline 21 & 15.58 & 344 & 463 & $301(100)$ & Quercetin-O-hexoside \\
\hline 22 & 15.62 & 335 & 491 & $311(100), 293(20), 197(12)$ & Salvianolic acid C \\
\hline 23 & 15.96 & 332 & 797 & $779(100), 599(42), 555(50), 359(37), 313(12), 169(5)$ & Unknown \\
\hline 24 & 16.66 & 351 & 769 & $315(100), 300(10)$ & Isorhamentin-3-O-rhamnosyl-rutinoside \\
\hline 25 & 17.02 & 332 & 421 & $153(100)$ & $\begin{array}{c}4-\left[\left[\left(2^{\prime}, 5^{\prime} \text { Dihydroxybenzoyl)oxy }\right] \text { methyl }\right] \text { phenyl- } O-\beta-\right. \\
\text { D-glucopyranoside }\end{array}$ \\
\hline
\end{tabular}


Table 3. Cont

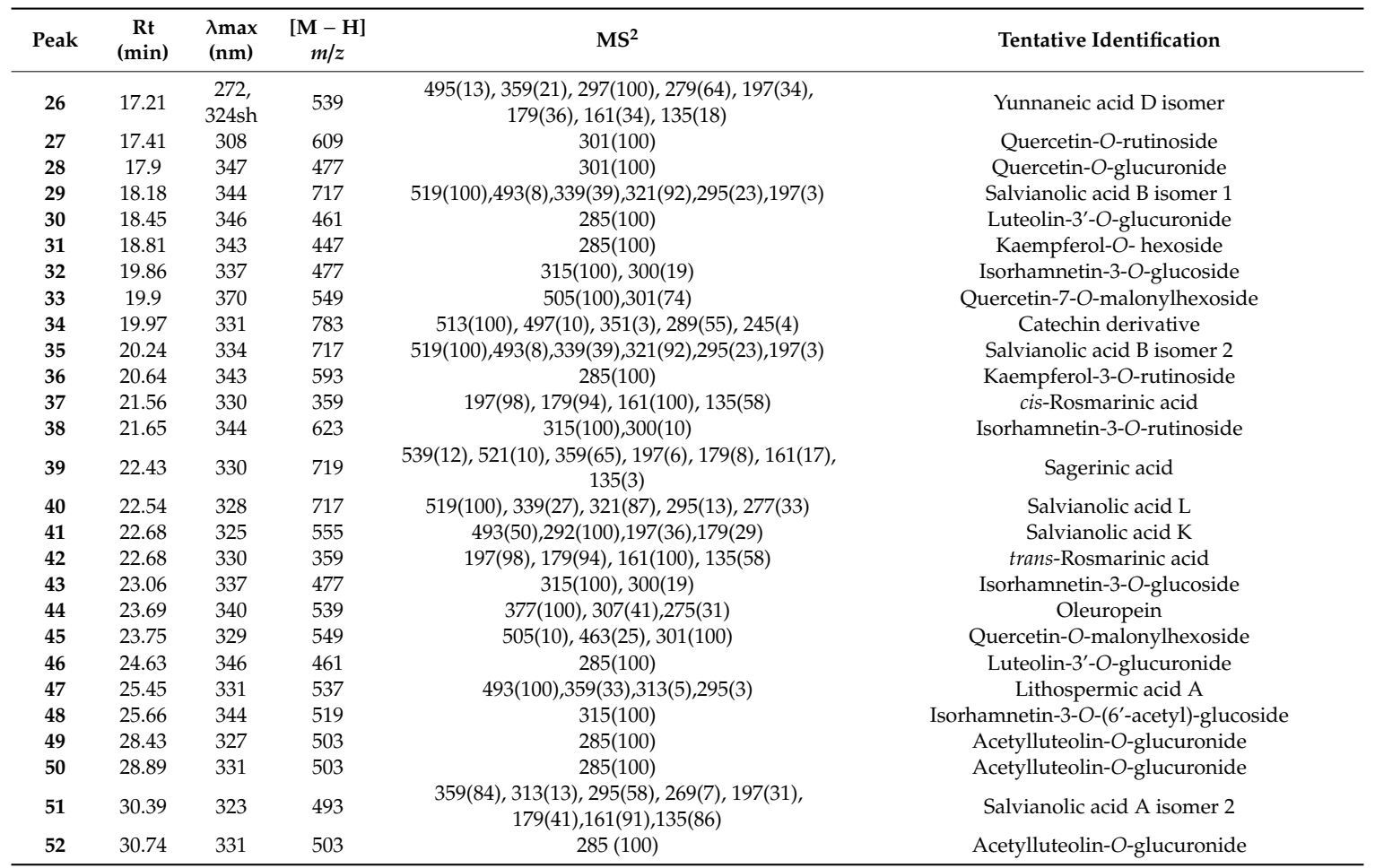

References used for identification: [6] for peaks 4 and 47; [9] for peaks 2, 28, 33, 45, and 46; [28] for peak 10; [21] for peaks 5 and 38; [22] for peak 7; [29] for peaks 1, 9, 15, 17, 18, 20, 21, 27, 36, and 41; [30] for peak 3; [31] for peaks 6, 25, and 31; [32] for peak 8; [33] for peaks 11, 13, and 30; [27] for peak 12; [34] for peak 14; [35] for peak 16; [25] for peaks $19,24,26,32,37,39,42$, and 48; [36] for peak 22; [37] for peaks 29 and 35; [38] for peak 34; [39] for peaks 40 and 51; [40] for peak 43; [24] for 44; [41] for peaks 49,50 , and 52 .

Table 4. Quantification of the phenolic compounds present in the six infused blends (mean \pm SD; $\mathrm{mg} / \mathrm{g}$ extract).

\begin{tabular}{|c|c|c|c|c|c|c|c|}
\hline Peak & Compounds & Mix 1 & Mix 2 & Mix 3 & $\operatorname{Mix} 4$ & Mix 5 & Mix 6 \\
\hline 1 & Caftaric acid & $1.60 \pm 0.01$ & nd & $1.8 \pm 0.2$ & nd & nd & nd \\
\hline 2 & 3-O-Caffeoylquinic acid & nd & $3.2 \pm 0.2^{\mathrm{a}}$ & nd & $2.15 \pm 0.02^{d}$ & $2.56 \pm 0.05^{c}$ & $2.7 \pm 0.1^{b}$ \\
\hline 3 & Epigallocatechin & $0.066 \pm 0.003$ & nd & nd & $1.3 \pm 0.1$ & nd & nd \\
\hline 4 & 4-O-Caffeoylquinic acid & $0.9 \pm 0.1^{c}$ & $1.6 \pm 0.1^{\mathrm{a}}$ & nd & nd & nd & $1.2 \pm 0.3^{b}$ \\
\hline 5 & (+)-Gallocatechin & $2.5 \pm 0.2$ & nd & nd & nd & nd & nd \\
\hline 6 & 5-O-Caffeoylquinic acid & nd & $22.4 \pm 0.2^{\mathrm{a}}$ & nd & nd & $1.0 \pm 0.1^{\mathrm{c}}$ & $1.6 \pm 0.2^{b}$ \\
\hline 7 & Tuberonic acid glucoside & $0.216 \pm 0.003$ & nd & nd & nd & nd & nd \\
\hline 8 & Eriodictyol-7-O-rutinoside & nd & nd & nd & nd & $0.69 \pm 0.01$ & nd \\
\hline 9 & Caffeic acid & $0.231 \pm 0.002$ & nd & nd & nd & nd & nd \\
\hline 10 & Salvianolic acid F & nd & nd & nd & $1.50 \pm 0.01$ & nd & nd \\
\hline 11 & Eriodictyol-O-hexoside isomer 1 & nd & nd & nd & nd & nd & $0.6 \pm 0.1$ \\
\hline 12 & 4-p-Coumaroylquinic acid & $0.33 \pm 0.04$ & nd & nd & nd & nd & nd \\
\hline 13 & Eriodictyol-O-hexoside isomer 2 & nd & nd & nd & nd & nd & $3.5 \pm 0.6$ \\
\hline 14 & Luteolin-O-di-glucuronide & nd & nd & nd & nd & $1.891 \pm 0.001$ & nd \\
\hline 15 & Chicoric acid & nd & nd & $3.5 \pm 0.4$ & nd & nd & nd \\
\hline 16 & Salvianolic acid $\mathrm{A}$ isomer 1 & nd & nd & nd & nd & $0.48 \pm 0.01$ & nd \\
\hline 17 & Lithospermic acid A & nd & nd & nd & $1.12 \pm 0.03$ & nd & nd \\
\hline 18 & Salvianolic acid K & $0.99 \pm 0.01$ & nd & nd & nd & nd & nd \\
\hline 19 & Rosmarinic acid hexoside & $0.86 \pm 0.03$ & nd & nd & nd & nd & nd \\
\hline 20 & Quercetin-3-O-rutinoside & nd & $31 \pm 1$ & nd & $0.20 \pm 0.03$ & nd & nd \\
\hline 21 & Quercetin-O-hexoside & nd & nd & nd & nd & nd & $8.9 \pm 0.1$ \\
\hline 22 & Salvianolic acid C & $0.82 \pm 0.03$ & nd & nd & nd & nd & nd \\
\hline 23 & Unknown & nd & nd & nd & nd & $\mathrm{nq}$ & nd \\
\hline 24 & Isorhamentin-3-O-rhamnosyl-rutinoside & nd & nd & nd & $2.51 \pm 0.05$ & nd & nd \\
\hline 25 & $\begin{array}{l}\text { 4-[[(2',5'Dihydroxybenzoyl)oxy]methyl]phenyl- } \\
\text { O- } \beta \text {-D-glucopyranoside }\end{array}$ & nd & nd & nd & nd & $14.6 \pm 0.2$ & nd \\
\hline 26 & Yannaneic acid D isomer & nd & nd & nd & $0.6 \pm 0.1$ & nd & nd \\
\hline 27 & Quercetin-O-rutinoside & nd & nd & $0.62 \pm 0.01$ & nd & nd & nd \\
\hline 28 & Quercetin-O-glucuronide & nd & nd & $1.98 \pm 0.05$ & $1.3 \pm 0.1$ & nd & nd \\
\hline 29 & Salvianolic acid B isomer 1 & nd & nd & $6.3 \pm 0.5$ & nd & $1.26 \pm 0.05$ & nd \\
\hline 30 & Luteolin-3'-O-glucuronide & $4.6 \pm 0.1$ & nd & nd & nd & nd & nd \\
\hline 31 & Kaempferol-O- hexoside & nd & nd & nd & nd & nd & $35 \pm 1$ \\
\hline 32 & Isorhamnetin-3-O-glucoside & $1.166 \pm 0.001$ & nd & nd & nd & nd & nd \\
\hline 33 & Quercetin-7-O-malonylhexoside & nd & $1.4 \pm 0.2$ & nd & nd & nd & nd \\
\hline 34 & Catechin derivative & nd & nd & nd & nd & $\mathrm{nq}$ & nd \\
\hline
\end{tabular}


Table 4. Cont.

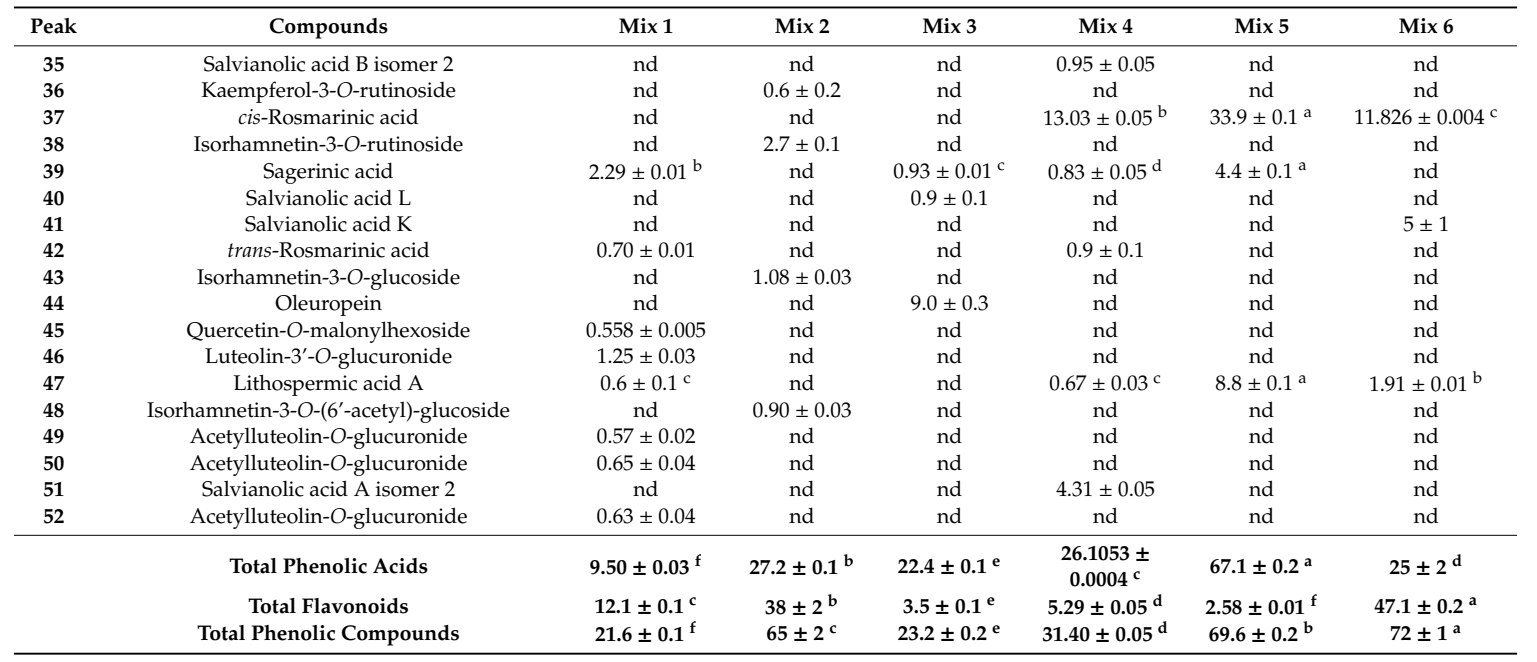

Note: nd: not detected; nq: not quantified. Mix 1: 50\% R. officinalis, 20\% C. nobile, $15 \%$ L. nobilis, $15 \%$ J. regia. Mix 2: $40 \%$ F. vulgare, $30 \%$ S. nigra, 30\% H. perforatum. Mix 3: $50 \%$ M. pulegium, $25 \%$ O. europaea, $25 \%$ V. vinifera. Mix 4: $60 \%$ M. cervine, $20 \%$ C. arvensis, $20 \%$ R. idaeus. Mix 5: $60 \%$ O. vulgare, $10 \%$ C. nobile, $15 \%$ L. nobilis, $15 \%$ J. regia. Mix 6: $70 \%$ T. mastichina, 15\% L. nobilis, $15 \%$ J. regia. Calibration curves: chlorogenic acid ( $y=168,823 x$ $-161,172 ; R^{2}=1.000 ; \mathrm{LOD}=0.20 \mu \mathrm{g} / \mathrm{mL} ; \mathrm{LOQ}=0.68 \mu \mathrm{g} / \mathrm{mL}$; peaks $1,2,4,6$, and 15$) ;$ epicatechin $(y=10,314 x$ $+147,331 ; R^{2}=0.9998 ; \mathrm{LOD}=0.15 \mu \mathrm{g} / \mathrm{mL} ; \mathrm{LOQ}=0.78 \mu \mathrm{g} / \mathrm{mL}$; peaks 3 and 5$) ; p$-coumaric acid $(y=301,950 x+$ 6966.7; $R^{2}=0.9999 ; \mathrm{LOD}=0.68 \mu \mathrm{g} / \mathrm{mL} ; \mathrm{LOQ}=1.61 \mu \mathrm{g} / \mathrm{mL}$; peaks 7 and 12$) ;$ naringenin $(y=18,433 \mathrm{x}+78,903$; $R^{2}=0.9997 ; \mathrm{LOD}=0.17 \mu \mathrm{g} / \mathrm{mL} ; \mathrm{LOQ}=0.81 \mu \mathrm{g} / \mathrm{mL}$; peaks 8 and 13$) ;$ caffeic acid $\left(y=388,345 x+406,369 ; R^{2}=\right.$ $0.9991 ; \mathrm{LOD}=0.78 \mu \mathrm{g} / \mathrm{mL} ; \mathrm{LOQ}=1.97 \mu \mathrm{g} / \mathrm{mL}$; peaks 9 and 12); rosmarinic acid $\left(y=191,291 x-652,903 ; R^{2}=\right.$ 0.999; $\mathrm{LOD}=0.15 \mu \mathrm{g} / \mathrm{mL} ; \mathrm{LOQ}=0.68 \mu \mathrm{g} / \mathrm{mL}$; peaks 10, 16, 17, 18, 19, 22, 26, 29, 35, 37, 39, 40, 41, 42, 47, and 51); quercetin-3-O-glucoside $\left(y=34,843 x-160,173 ; R^{2}=1.000 ;\right.$ LOD $0.21 \mu \mathrm{g} / \mathrm{mL} ; \mathrm{LOQ} 0.71 \mu \mathrm{g} / \mathrm{mL}$; peaks $14,21,28,32$, $33,43,45,46,48,49,50$, and 52); quercetin-3-O-rutinoside $\left(y=13,343 x+76,751 ; R^{2}=0.9998 ; \mathrm{LOD} 0.18 \mu \mathrm{g} / \mathrm{mL} ; \mathrm{LOQ}\right.$ $0.65 \mu \mathrm{g} / \mathrm{mL}$; peaks 20, 24, 27, 30,31,36, and 38); protocatechuic acid $\left(y=214,168 x+27,102 ; R^{2}=0.9997 ; \mathrm{LOD}=\right.$ $0.14 \mu \mathrm{g} / \mathrm{mL} ; \mathrm{LOQ}=0.52 \mu \mathrm{g} / \mathrm{mL}$; peak 25); oleuropein $\left(y=32,226 x+12,416 ; R^{2}=0.9997 ; \mathrm{LOD}=0.69 \mu \mathrm{g} / \mathrm{mL}\right.$ and $\mathrm{LOQ}=1.96 \mu \mathrm{g} / \mathrm{mL}$; peak 44). The statistical treatment was performed by comparing the mixes; therefore, in each row different letters indicate statistically significant differences $(p<0.05)$. Mean statistical differences obtained by Student's $t$-test for peaks $1,3,20,28,29$, and 42 was $<0.001$.

Regarding the total compositions of phenolic compounds, it was possible to verify that mix 6 , mix 5 , and mix 2 presented higher contents of total phenolic compounds $(72 \pm 1,69.6 \pm 0.2$, and $65 \pm 2 \mathrm{mg} / \mathrm{g}$ extract, respectively). In mix 5, the total phenolic compound quantity is mainly due to the presence of phenolic acids (67.1 $\pm 0.2 \mathrm{mg} / \mathrm{g}$ extract), which represents $96 \%$ of the total phenolic composition. In mix 6 , the total phenolic compound quantity is mainly due to the total flavonoid content $(47.1 \pm 0.2 \mathrm{mg} / \mathrm{g}$ extract), which represents $65.4 \%$ of the total composition.

\subsection{Bioactive Properties}

The results for antioxidant, anti-inflammatory, and cytotoxic activities are shown in Table 5.

For TBARS assays, mix 1 and mix 6 presented the lowest $\mathrm{IC}_{50}$ values $(4.5 \pm 0.2$ and $6.9 \pm 0.3 \mu \mathrm{g} / \mathrm{mL}$, respectively), which indicates high antioxidant activity. In fact, mix 1 revealed a higher lipid peroxidation inhibition capacity than the positive control, Trolox $(5.8 \pm 0.6 \mu \mathrm{g} / \mathrm{mL})$. This activity could be explained by the presence of $R$. officinalis, reported in the literature as an excellent antioxidant plant, which is even applied in foodstuffs such as cottage cheese to increase shelf life [6]. Regarding the good results found for mix 6, the fact is that this blend presented the highest concentration of phenolic compounds, which are often reported as the main compounds responsible for the bioactive properties of plants. In a previous study, O. vulgare infusion presented an $\mathrm{IC}_{50}$ value of $22.8 \pm 0.5 \mu \mathrm{g} / \mathrm{mL}$, which was a high concentration when compared to $9 \pm 1 \mu \mathrm{g} / \mathrm{mL}$, the $\mathrm{IC}_{50}$ value obtained for mix 5 (with $60 \%$ of this plant), thus suggesting synergistic effects among the blended plants [26].

In terms of antihemolytic activity, the blend revealing the best results was mix 5 , with an $\mathrm{IC}_{50}$ value of $4.0 \pm 0.6 \mu \mathrm{g} / \mathrm{mL}$. In fact, this blend presented the highest concentration of phenolic acids, which could be related to its antioxidant properties. All blends, with the exception of mix 2, revealed 
lower $\mathrm{IC}_{50}$ values than the positive control $(85 \pm 2 \mu \mathrm{g} / \mathrm{mL})$. Studies developed by Caleja et al. [42] and Ribeiro et al. [43] proved the high antioxidant and antimicrobial potential of F. vulgare (present in mix 2) and R. officinalis (present in mix 1) and their capacity to increase the shelf life of functionalized foods. Moreover, in a previous study, S. nigra (present in mix 2) also revealed antioxidant properties (DPPH and FRAP assays) [44]. It is also reported in the literature that the combination of several plants in a drink beverage can provide a synergistic effect in terms of bioactivities, as their combination improves the antioxidant status and reduces oxidative stress [45].

Table 5. Antioxidant, anti-inflammatory, and cytotoxic activity of the six infused blends (mean \pm SD).

\begin{tabular}{|c|c|c|c|c|c|c|}
\hline & $\operatorname{Mix} 1$ & $\operatorname{Mix} 2$ & $\operatorname{Mix} 3$ & $\operatorname{Mix} 4$ & $\operatorname{Mix} 5$ & $\operatorname{Mix} 6$ \\
\hline \multicolumn{7}{|l|}{$\begin{array}{l}\text { Antioxidant activity } \\
\quad\left(\mathrm{IC}_{50}, \mu \mathrm{g} / \mathrm{mL}\right)\end{array}$} \\
\hline TBARS & $4.5 \pm 0.2^{f}$ & $23.1 \pm 0.3^{\mathrm{a}}$ & $14 \pm 1^{\mathrm{c}}$ & $22 \pm 1^{b}$ & $9 \pm 1^{d}$ & $6.9 \pm 0.3^{\mathrm{e}}$ \\
\hline OxHLIA $(\Delta t=60 \mathrm{~min})$ & $22 \pm 1^{c}$ & $106 \pm 4^{\mathrm{a}}$ & $9.7 \pm 0.7^{\mathrm{e}}$ & $12 \pm 2^{d}$ & $4.0 \pm 0.6^{f}$ & $35 \pm 2^{b}$ \\
\hline \multicolumn{7}{|l|}{$\begin{array}{l}\text { Cytotoxic activity } \\
\left(\mathrm{GI}_{50}, \mu \mathrm{g} / \mathrm{mL}\right)\end{array}$} \\
\hline MCF-7 & $209 \pm 5^{c}$ & $>400$ & $238 \pm 4^{b}$ & $>400$ & $236 \pm 16^{b}$ & $254 \pm 17^{\mathrm{a}}$ \\
\hline NCI-H460 & $257 \pm 10^{b}$ & $>400$ & $320 \pm 12^{a}$ & $>400$ & $250 \pm 13^{b}$ & $258 \pm 16^{b}$ \\
\hline HeLa & $246 \pm 16^{a}$ & $>400$ & $217 \pm 11^{\mathrm{c}}$ & $>400$ & $213 \pm 9^{c}$ & $227 \pm 10^{b}$ \\
\hline HepG2 & $226 \pm 13^{b}$ & $>400$ & $304 \pm 6^{a}$ & $>400$ & $230 \pm 25^{b}$ & $175 \pm 18^{\mathrm{c}}$ \\
\hline PLP2 & $>400$ & $>400$ & $>400$ & $>400$ & $>400$ & $>400$ \\
\hline \multicolumn{7}{|l|}{$\begin{array}{c}\text { Anti-inflammatory } \\
\text { activity }\left(\mathrm{IC}_{50}, \mu \mathrm{g} / \mathrm{mL}\right)\end{array}$} \\
\hline RAW 246.7 & $321 \pm 4^{\mathrm{a}}$ & $>400$ & $276 \pm 12^{b}$ & $>400$ & $276 \pm 12^{b}$ & $262 \pm 17^{c}$ \\
\hline
\end{tabular}

Mix 1: 50\% R. officinalis, 20\% C. nobile, $15 \%$ L. nobilis, $15 \%$ J. regia. Mix 2: $40 \%$ F. vulgare, $30 \%$ S. nigra, $30 \% \mathrm{H}$. perforatum. Mix 3: 50\% M. pulegium, 25\% O. europaea, 25\% V. vinifera. Mix 4: $60 \%$ M. cervine, 20\% C. arvensis, 20\% R. idaeus. Mix 5: 60\% O. vulgare, 10\% C. nobile, 15\% L. nobilis, $15 \%$ J. regia. Mix 6: $70 \%$ T. mastichina, $15 \%$ L. nobilis, $15 \% \mathrm{~J}$. regia. $\mathrm{EC}_{50}$ values corresponded to the extract concentration that inhibits $50 \%$ of the oxidation and inflammatory processes. Trolox ( $\mathrm{IC}_{50}$ values): TBARS (thiobarbituric acid reactive species): $5.8 \pm 0.6 \mu \mathrm{g} / \mathrm{mL}$; OxHLIA (oxidative hemolysis inhibition, $60 \mathrm{~min}$ ): $85 \pm 2 \mu \mathrm{g} / \mathrm{mL}$. Dexamethasone (IC 50 values): $16 \pm 1 \mu \mathrm{g} / \mathrm{mL}$. $\mathrm{GI}_{50}$ values correspond to the concentration that causes $50 \%$ inhibition of cell proliferation. Note: MCF-7 = human breast adenocarcinoma; NCI-H460 = human lung carcinoma; HeLa = human cervix adenocarcinoma; HepG2 = hepatocellular carcinoma; PLP2 = primary culture of non-tumoral pig liver cells. Ellipticine (GI ${ }_{50}$ values): MCF-7: $1.21 \pm 0.02 \mu \mathrm{g} / \mathrm{mL}$; NCI-H460: $0.91 \pm 0.11 \mu \mathrm{g} / \mathrm{mL}$; HeLa: $1.03 \pm 0.09 \mu \mathrm{g} / \mathrm{mL} ;$ HepG2: $1.1 \pm 0.09 \mu \mathrm{g} / \mathrm{mL} ;$ PLP2: $2.29 \pm$ $0.18 \mu \mathrm{g} / \mathrm{mL}$. Raw 246.7 (Mouse lipopolysaccharide (LPS)-stimulated macrophage-like cell line). Results expressed as mean values \pm standard deviation (SD). The statistical treatment was performed by comparing the mixtures; therefore, in each row different letters indicate statistically significant differences $(p<0.05)$.

Regarding cytotoxic activity, except for mix 2 and mix 4, all blends revealed the capacity to inhibit the growth of the studied tumor cell lines in concentrations ranging from $175 \pm 18$ (mix 6 in HepG2) to $320 \pm 12$ (mix 3 in NCI-H460) $\mu \mathrm{g} / \mathrm{mL}$. Another positive aspects is that none of the mixtures revealed toxicity for non-tumor cells up to $400 \mu \mathrm{g} / \mathrm{mL}$.

Similar observations could be made for anti-inflammatory activity, with mix 2 and mix 4 being the only blends not showing activity. Among the remaining infusions, mix 6 revealed the highest activity at a concentration of $262 \pm 17 \mu \mathrm{g} / \mathrm{mL}$. Considering the results reported by Dias et al. [11] and Vieira et al. [27], where L. nobilis and J. regia presented cytotoxic activity, in the present study it was expected that mix 2 and mix 4, containing these plants, would also present these properties, which was not observed. This was possibly due to the fact that such blends also included other species.

Finally, Table 6 shows the antimicrobial capacity of the six infused blends. It is possible to confirm the excellent antimicrobial potential of all mixtures against the analyzed microorganisms. S. aureus and P. funiculosum seemed to be the most sensitive microorganisms tested, with the infusions revealing lower minimal inhibitory concentration (MIC) and minimal bactericidal concentration/minimal fungal concentration (MBC/MFC) values than the positive controls. Among the tested blends, mix 1 revealed the highest antibacterial properties, with inhibitory and bactericidal concentrations ranging between 0.25 and $2 \mathrm{mg} / \mathrm{mL}$. These results are in accordance with the ones obtained for R. officinalis (50\% of the 
composition of mix 1) hydroethanolic extracts, which showed promising antimicrobial capacity [41]. On the other hand, mix 6 revealed the greatest antifungal activity, being able to inhibit fungal growth at 0.12 to $0.5 \mathrm{mg} / \mathrm{mL}$ and presenting fungicidal capacity in concentrations ranging from 0.25 to $5 \mathrm{mg} / \mathrm{mL}$. This blend was more effective than the positive controls for all the tested fungi, except in terms of killing A. fumigatus. These results are in accordance with the ones obtained for Thymus sp. (70\% of the composition of mix 6), which has been prescribed for the treatment of infectious diseases [33]. The antimicrobial capacity of Thymus sp. infusion has often been correlated with the presence of flavonoids and phenolic acids $[6,21,46]$.

Table 6. Antimicrobial activity of the six infused blends and positive controls.

\begin{tabular}{|c|c|c|c|c|c|c|c|c|c|c|c|c|c|c|c|c|}
\hline \multirow{2}{*}{$\begin{array}{c}\text { Antibacterial activity } \\
(\mathrm{mg} / \mathrm{mL}) \\
\text { Bacteria }\end{array}$} & \multicolumn{2}{|c|}{ Mix 1} & \multicolumn{2}{|c|}{$\operatorname{Mix} 2$} & \multicolumn{2}{|c|}{$\operatorname{Mix} 3$} & \multicolumn{2}{|c|}{$\operatorname{Mix} 4$} & \multicolumn{2}{|c|}{$\operatorname{Mix} 5$} & \multicolumn{2}{|c|}{ Mix 6} & \multicolumn{2}{|c|}{ E221 } & \multicolumn{2}{|c|}{ E224 } \\
\hline & MIC & $\mathrm{MBC}$ & MIC & MBC & MIC & MBC & MIC & MBC & MIC & MBC & MIC & $\mathrm{MBC}$ & MIC & MBC & MIC & MBC \\
\hline \multicolumn{17}{|l|}{ Gram-negative } \\
\hline $\begin{array}{c}\text { Salmonella } \\
\text { Typhymurium }\end{array}$ & 0.5 & 1 & 4 & 8 & 1 & 2 & 2 & 2 & 1 & 2 & 1 & 1 & 1 & 2 & 1 & 1 \\
\hline $\begin{array}{c}\text { Enterobacter cloacae } \\
\text { Gram-positive }\end{array}$ & 0.5 & 1 & 2 & 2 & 1 & 2 & 1 & 2 & 1 & 2 & 1 & 2 & 2 & 4 & 0.5 & 0.5 \\
\hline Bacillus cereus & 1 & 1 & 1 & 2 & 1 & 2 & 1 & 2 & 1 & 2 & 1 & 1 & 0.5 & 0.5 & 2 & 4 \\
\hline Listeria monocytogenes & 0.5 & 1 & 2 & 2 & 1 & 2 & 1 & 2 & 1 & 2 & 1 & 2 & 1 & 2 & 0.5 & 1 \\
\hline Staphylococcus aureus & 0.25 & 0.25 & 1 & 1 & 0.25 & 0.5 & 0.25 & 0.25 & 0.25 & 0.5 & 0.25 & 0.5 & 4 & 4 & 1 & 1 \\
\hline Micrococcus flavus & 2 & 2 & 2 & 4 & 2 & 4 & 1 & 2 & 1 & 2 & 1 & 2 & 1 & 2 & 1 & 2 \\
\hline \multicolumn{17}{|l|}{$\begin{array}{c}\text { Antifungal activity } \\
(\mathrm{mg} / \mathrm{mL})\end{array}$} \\
\hline Aspergillus niger & 0.5 & 1 & 0.5 & 1 & 1 & 1 & 0.5 & 1 & 0.5 & 1 & 0.25 & 0.5 & 1 & 2 & 1 & 1 \\
\hline Aspergillus versicolor & 0.5 & 1 & 0.5 & 1 & 1 & 1 & 0.5 & 0.5 & 0.5 & 1 & 0.25 & 0.5 & 2 & 2 & 1 & 1 \\
\hline Aspergillus fumigatus & 0.5 & 1 & 0.5 & 1 & 1 & 1 & 0.5 & 1 & 1 & 2 & 0.25 & 5 & 1 & 2 & 1 & 1 \\
\hline $\begin{array}{l}\text { Penicillium } \\
\text { funiculosum }\end{array}$ & 0.25 & 0.5 & 0.5 & 0.5 & 0.25 & 0.5 & 0.12 & 0.25 & 0.12 & 0.25 & 0.12 & 0.25 & 1 & 2 & 0.5 & 0.5 \\
\hline $\begin{array}{l}\text { Penicillium } \\
\text { aurantiogriseum }\end{array}$ & 0.5 & 1 & 1 & 2 & 0.5 & 1 & 1 & 2 & 0.5 & 1 & 0.5 & 1 & 2 & 4 & 1 & 1 \\
\hline
\end{tabular}

Note: $\mathrm{MIC}=$ minimal inhibitory concentration; $\mathrm{MBC}=$ minimal bactericidal concentration; $\mathrm{MFC}=$ minimal fungal concentration. Mix 1: 50\% R. officinalis, 20\% C. nobile, 15\% L. nobilis, 15\% J. regia. Mix 2: $40 \%$ F. vulgare, 30\% S. nigra, $30 \%$ H. perforatum. Mix 3: 50\% M. pulegium, 25\% O. europaea, 25\% V. vinifera. Mix 4: 60\% M. cervine, 20\% C. arvensis, 20\% R. idaeus. Mix 5: 60\% O. vulgare, 10\% C. nobile, 15\% L. nobilis, 15\% J. regia. Mix 6: 70\% T. mastichina, 15\% L. nobilis, $15 \%$ J. regia.

\section{Materials and Methods}

\subsection{Samples and Infusions Preparation}

Each dry plant material used to prepare the blends was provided by Ervital ${ }^{\circledR}$ (company based in Castro Daire, Portugal). The botanical identification of the fifteen samples was confirmed by Professor Doctor Ana Maria Carvalho (Polytechnic Institute of Bragança, Trás-os-Montes, Portugal) and consisted of: (i) flowering aerial parts of Foeniculum vulgare Mill., Hypericum perforatum L., Mentha cervina L., Mentha pulegium L., Origanum vulgare subs. virens Hoffm. and Link, and Thymus mastichina L; (ii) flower heads of Calendula arvensis L., Chamaemelum nobile (L.) All., and Sambucus nigra L.; and (iii) leaves of Juglans regia L., Laurus nobilis L., Olea europaea L., Rosmarinus officinalis L., Rubus idaeus L., and Vitis vinifera L. The six herbal mixtures (mix 1 to mix 6) were blended based on their folk uses and sensory characteristics, following the proportions and traditional combinations of such species: Mix 1: 50\% R. officinalis, 20\% C. nobile, 15\% L. nobilis, and 15\% J. regia.; mix 2: 40\% F. vulgare, 30\% S. nigra, and 30\% H. perforatum; $\operatorname{mix} 3$ : 50\% M. pulegium, 25\% O. europaea, and 25\% V. vinifera; mix 4: 60\% M. cervine, 20\% C. arvensis, and 20\% R. idaeus; mix 5: 60\% O. vulgare, $10 \%$ C. nobile, $15 \%$ L. nobilis, and 15\% J. regia.; mix 6: 70\% T. mastichina, 15\% L. nobilis, and 15\% J. regia. All the samples were reduced to a fine powder and protected from light and humidity until further analysis. Furthermore, the preparation of infusions was based on the protocol previously described by Pereira et al. [47] and following particular extraction conditions for each blend: $\operatorname{mix} 1: 10 \mathrm{~g} / \mathrm{L}, 95{ }^{\circ} \mathrm{C}, 5-7 \mathrm{~min} ; \operatorname{mix} 2: 10 \mathrm{~g} / \mathrm{L}, 90^{\circ} \mathrm{C}, 4-6 \mathrm{~min} ; \operatorname{mix} 3: 4 \mathrm{~g} / \mathrm{L}$, 
$95^{\circ} \mathrm{C}, 5-8 \mathrm{~min}$; $\operatorname{mix} 4: 4 \mathrm{~g} / \mathrm{L}, 90{ }^{\circ} \mathrm{C}, 4-6 \mathrm{~min}$; $\operatorname{mix} 5: 10 \mathrm{~g} / \mathrm{L}, 90^{\circ} \mathrm{C}, 5-7 \mathrm{~min}$; and $\operatorname{mix} 6: 10 \mathrm{~g} / \mathrm{L}, 90{ }^{\circ} \mathrm{C}$, 5-7 min. All samples were filtered through Whatman \# 4 paper, frozen at $-20^{\circ} \mathrm{C}$, and then lyophilized. The extracts were protected from light and humidity until further analysis.

\subsection{Nutritional Analysis and Sugar Content}

Fat, carbohydrate, ash, and protein contents of the six dry infusion extracts were analyzed following the AOAC [48] procedures. Free sugars were analyzed following the method previously described by Barros et al. [28], using HPLC coupled to a refractive index detector (Knauer, Smartline 1000 and Smartline 2300 systems, respectively) and melezitose as internal standard. The results were expressed in $\mathrm{mg} / 100 \mathrm{~mL}$ of infusion. Finally, the energetic value was calculated according the equation: energy $(\mathrm{cal})=4 \times(\mathrm{mg}$ proteins $+\mathrm{mg}$ carbohydrates $)+9 \times(\mathrm{mg}$ lipids $)$.

\subsection{Phenolic Compounds Composition}

The dry infusion extracts were resuspended in water at a concentration of $10 \mathrm{mg} / \mathrm{mL}$. The phenolic profile was determined by liquid chromatography (Dionex Ultimate 3000 UPLC, Thermo Scientific, San Jose, CA, USA) with a diode array detector $(280,330$, and $370 \mathrm{~nm}$ wavelengths) equipped with an ESI source and working in negative mode (Linear Ion Trap LTQ XL, Thermo Scientific, San Jose, CA, USA) [49]. Chromatographic separation was achieved with a Waters Spherisorb S3 ODS-2C18 ( $3 \mathrm{~m}, 4.6 \mathrm{~mm} \times 150 \mathrm{~mm}$, Waters, Mil-ford, MA, USA) column thermostat at $35^{\circ} \mathrm{C}$. The solvents used were: (A) $0.1 \%$ formic acid in water, (B) acetonitrile. The established isocratic elution gradient was 15\% B (5 min), 15\% B to 20\% B (5 min), 20-25\% B (10 min), 25-35\% B (10 min), 35-50\% B (10 min), and re-equilibration of the column, using a flow rate of $0.5 \mathrm{~mL} / \mathrm{min}$ [49]. The phenolic compounds were identified by comparing their retention times, UV, and mass spectra values with those obtained from standard compounds and with the literature. For quantitative analysis, 7-level calibration curves prepared with appropriate standards were used. The results were expressed in mg per g of dry extract $(\mathrm{mg} / \mathrm{g})$ as mean \pm standard deviation of three independent analyses.

\subsection{Evaluation of Bioactive Properties}

\subsubsection{Antioxidant Activity}

All samples were tested by two in vitro assays. The thiobarbituric acid reactive species (TBARS) assay uses a brain porcine homogenate measured by spectrophotometry at $532 \mathrm{~nm}$ [28]. This assay is used to determine the TBARS content in various samples, including those used to detect a sort of protective activity (usually antilipoperoxidant activity) using a fat or membrane model and an oxidant to induce the damage. The oxidative hemolysis inhibition (OxHLIA) assay is used to evaluate the antihemolytic activity of the extracts using sheep erythrocytes, measured by spectrophotometry at $690 \mathrm{~nm}$ [50]. Hemolysis was previously induced using 2,2'-Azobis(2-amidinopropane) dihydrochloride (AAPH). The results were expressed as $\mathrm{EC}_{50}$ values (sample concentration providing $50 \%$ of antioxidant activity, shown in $\mu \mathrm{g} / \mathrm{mL}$ ), and Trolox was used as a positive control for both assays.

\subsubsection{Anti-inflammatory Activity}

The anti-inflammatory activity was assessed following a procedure described by Svobodova et al. [51]. The dried extracts were re-dissolved in water at $8 \mathrm{mg} / \mathrm{mL}$ and evaluated in mouse lipopolysaccharide (LPS)-stimulated macrophage-like cell line RAW 264.7. The results were expressed as $\mathrm{IC}_{50}$ values (sample concentration providing $50 \%$ of anti-inflammatory activity, $\mu \mathrm{g} / \mathrm{mL}$ ) and dexamethasone $(50 \mu \mathrm{M})$ was used as a positive control.

\subsubsection{Cytotoxic Activity in Tumor and Non-Tumor Cells}

The cytotoxic potential was evaluated in four different human tumor cell lines (HeLa (cervical carcinoma), HepG2 (hepatocellular carcinoma), MCF-7 (breast adenocarcinoma), and NCI-H460 
(non-small-cell lung cancer)) and a primary culture of non-tumor cells (PLP2 (porcine liver)). To monitor the growth of cell cultures, which were sub-cultured and plated in 96-well plates (density of $1.0 \times 10^{4}$ cells/well), a phase-contrast microscope was used, following the protocol defined by Guimarães et al. [8]. Ellipticin was used as a positive control, and the results were expressed as $\mathrm{GI}_{50}$ values (sample concentration that inhibited $50 \%$ of cell growth, $\mu \mathrm{g} / \mathrm{mL}$ ).

\subsubsection{Antimicrobial Activity}

The antibacterial activity was evaluated using Gram (+) bacteria (Bacillus cereus (food isolate), Listeria monocytogenes (NCTC 7973), Staphylococcus aureus (ATCC 6538), and Micrococcus flavus (ATCC 10240)), as well as Gram (-) bacteria (Enterobacter cloacae (human isolate) and Salmonella Typhymurium (ATCC 13311)), following a protocol previously described by Soković et al. [46]. On the other hand, Aspergillus niger (ATCC 6275), Aspergillus versicolor (ATCC 11730), Aspergillus fumigatus (ATCC 9197), Penicillium funiculosum (ATCC 36839), and Penicillium aurantiogriseum (food isolate) were used to evaluate the antifungal activity, following the protocol described by Soković and Van Griensven [52]. Sodium sulphite (E221) and potassium metabisulphite (E224) food additives were used as positive controls for both activities. The microorganisms are deposited at the Institute for Biological Research "Siniša Stanković", National Institute of Republic of Serbia, University of Belgrade. The results were expressed as minimal inhibitory concentration (MIC), minimal bactericidal concentration $(\mathrm{MBC})$, and minimal fungicidal concentration (MFC) values.

\subsection{Statistical Analysis}

For each herbal blend, three individual samples were analyzed, and all assays were prepared in triplicate. The results were analyzed using one-way analysis of variance (ANOVA), followed by Tukey's HSD test as $p=0.05$, and are expressed as mean values with standard deviation (SD). When less than three results were present in each individual analysis, Student's $t$-test $p$-values were used to determine the significant difference, with $p=0.05$. Both of these statistical treatments were carried out using the SPSS v.22.0 program.

\section{Conclusions}

The infusions of different blended species proved to be valuable sources of high-added-value compounds and also showed high capacity for bioactive activity. Given the wide variety of species in each sample, a great variability in results was also expected, rather than obtaining a mixture that stood out in terms of all the analyzed parameters. However, mix 5 had higher contents of soluble sugar, energy contribution, total phenolic acids, and a higher capacity to inhibit erythrocyte hemolysis and the proliferation of the HeLa tumor cell line. Mix 6 presented the highest content of total phenolic compounds (especially flavonoids), higher capacity to inhibit the growth of HepG2 tumor cell line, higher anti-inflammatory activity, and higher antifungal activity. Finally, mix 1 revealed a higher capacity to inhibit lipid peroxidation in the TBARS assay, higher capacity to inhibit the growth of the MCF-7 tumor cell line, and higher antibacterial potential, presenting the lowest MIC and MBC values for Gram-positive and Gram-negative bacteria (even lower than the positive controls). The fact that blends 1, 5, and 6 contain 15\% L. nobilis and 15\% J. regia in their composition could explain the better results obtained with these plant mixtures compared to the other ones that did not contain any of these species. As stated earlier, L. nobilis and J. regia have already been described as highly promising plants for obtaining high-added-value compounds with bioactive potential. Future studies will be necessary to evaluate the real synergistic effects presented by these two plants in the presence of others, and to evaluate their potential for further application in various food, pharmaceutical, and nutraceutical products.

Author Contributions: Conceptualization, A.M.C., E.R., L.B., and I.C.F.R.F.; formal analysis, T.C.F., C.P., M.I.D., C.C., R.C.C., and A.M.C.; funding acquisition, I.C.F.R.F; investigation, T.C.F., C.P., M.I.D., C.C., M.S., D.S., and L.B.; methodology, T.C.F., C.P., M.I.D., C.C., R.C.C., M.S., D.J., and L.B.; writing-original draft, T.C.F., C.P., M.I.D., 
C.C., and L.B.; writing-review and editing, A.M.C., E.R., and I.C.F.R.F. All authors have read and agreed to the published version of the manuscript.

Funding: The authors are grateful to the Foundation for Science and Technology (FCT, Portugal) and FEDER (Fundo Europeu de Desenvolvimento Regional) under Programme PT2020 for financial support to CIMO (Centro de Investigação de Montanha) (UIDB/00690/2020); national funding by FCT, P.I., through the Institutional Scientific Employment Program as contracts for L. Barros, R. C. Calhelha, and M.I. Dias, and for C. Pereira's contract through the celebration of program (contract foreseen in No. 4, 5, and 6 of article 23 of Decree-Law No. 57/2016, of 29th August, amended by Law No. 57/2017, of 19th July); to Project AllNat for the contract of C. Caleja (Project AllNat POCI-01-0145-FEDER-030463); and to FEDER-Interreg España-Portugal program for financial support through the 0377_Iberphenol_6_E project. This work was also supported by the European Investment Funds by FEDER/COMPETE/POCI Operacional Competitiveness and Internacionalizaon Programme, under project POCI-01-0145-FEDER-006958, and by National Funds by Portuguese Foundation for Science and Technology (FCT) under the project UID/AGR/04033/2013. This work was supported by the Ministry of Education, Science, and Technological Development of the Republic of Serbia (451-03-68/2020-14/200007).

Acknowledgments: The authors are also grateful to Ervital company (Castro Daire, Portugal) for providing the plant samples.

Conflicts of Interest: The authors declare no conflict of interest.

\section{References}

1. Tewari, D.; Samoila, O.; Gocan, D.; Mocan, A.; Moldovan, C.; Devkota, H.P.; Atanasov, A.G.; Zengin, G.; Echeverría, J.; Vodnar, D.; et al. Medicinal plants and natural products used in cataract management. Front. Pharmacol. 2019, 10, 466. [CrossRef] [PubMed]

2. Wachtel-Galor, S.; Benzie, I.F.F. Herbal Medicine: An Introduction to Its History, Usage, Regulation, Current Trends, and Research Needs; CRC Press: Boca Raton, FL, USA; Taylor \& Francis: Abington, Thames, UK, 2011; ISBN 9781439807132.

3. Li, S.; Li, S.-K.; Gan, R.-Y.; Song, F.-L.; Kuang, L.; Li, H.-B. Antioxidant capacities and total phenolic contents of infusions from 223 medicinal plants. Ind. Crops Prod. 2013, 51, 289-298. [CrossRef]

4. Karar, M.G.E.; Kuhnert, N. Herbal Drugs from Sudan: Traditional Uses and Phytoconstituents. Pharmacogn. Rev. 2017, 11, 83-103. [CrossRef] [PubMed]

5. Bekut, M.; Brkić, S.; Kladar, N.; Dragović, G.; Gavarić, N.; Božin, B. Potential of selected Lamiaceae plants in anti(retro)viral therapy. Pharmacol. Res. 2018, 133, 301-314. [CrossRef]

6. Ribeiro, A.; Caleja, C.; Barros, L.; Santos-Buelga, C.; Barreiro, M.F.; Ferreira, I.C.F.R. Rosemary extracts in functional foods: Extraction, chemical characterization and incorporation of free and microencapsulated forms in cottage cheese. Food Funct. 2016, 7, 2185-2196. [CrossRef]

7. Barros, L.; Heleno, S.A.; Carvalho, A.M.; Ferreira, I.C.F.R. Lamiaceae often used in Portuguese folk medicine as a source of powerful antioxidants: Vitamins and phenolics. LWT Food Sci. Technol. 2010, 43, 544-550. [CrossRef]

8. Guimarães, R.; Calhelha, R.C.; Froufe, H.J.C.; Abreu, R.M.V.; Carvalho, A.M.; Queiroz, M.J.R.P.; Ferreira, I.C.F.R. Wild Roman chamomile extracts and phenolic compounds: enzymatic assays and molecular modelling studies with VEGFR-2 tyrosine kinase. Food Funct. 2016, 7, 79-83. [CrossRef]

9. Guimarães, R.; Barros, L.; Dueñas, M.; Calhelha, R.C.; Carvalho, A.M.; Santos-Buelga, C.; Queiroz, M.J.R.P.; Ferreira, I.C.F.R. Nutrients, phytochemicals and bioactivity of wild Roman chamomile: A comparison between the herb and its preparations. Food Chem. 2013, 136, 718-725. [CrossRef]

10. Abudunia, A.M.; Marmouzi, I.; Faouzi, M.E.A.; Ramli, Y.; Taoufik, J.; El Madani, N.; Essassi, E.M.; Salama, A.; Khedid, K.; Ansar, M.; et al. Activité anti-candidose, antibactérienne, cytotoxique et antioxydante des fleurs de Calendula arvensis. J. Mycol. Med. 2017, 27, 90-97. [CrossRef]

11. Dias, M.I.; Barreira, J.C.M.; Calhelha, R.C.; Queiroz, M.J.R.P.; Oliveira, M.B.P.P.; Soković, M.; Ferreira, I.C.F.R. Two-dimensional PCA highlights the differentiated antitumor and antimicrobial activity of methanolic and aqueous extracts of Laurus nobilis L. from different origins. Biomed Res. Int. 2014, 2014. [CrossRef]

12. Omar, S.H. Oleuropein in olive and its pharmacological effects. Sci. Pharm. 2010, 78, 133-154. [CrossRef] [PubMed]

13. Peixoto, C.M.; Dias, M.I.; Alves, M.J.; Calhelha, R.C.; Barros, L.; Pinho, S.P.; Ferreira, I.C.F.R. Grape pomace as a source of phenolic compounds and diverse bioactive properties. Food Chem. 2018, 253, 132-138. [CrossRef] [PubMed] 
14. Miguel, M.G.; Cruz, C.; Faleiro, L.; Simoes, M.T.; Figueiredo, A.C.; Barroso, J.G.; Pedro, L.G. Foeniculum vulgare essential oils: chemical composition, antioxidant and antimicrobial activities. Nat. Prod. Commun. 2010, 5, 319-328. [CrossRef] [PubMed]

15. Jabeur, I.; Tobaldini, F.; Martins, N.; Barros, L.; Martins, I.; Calhelha, R.C.; Henriques, M.; Silva, S.; Achour, L.; Santos-Buelga, C.; et al. Bioactive properties and functional constituents of Hypericum androsaemum L.: A focus on the phenolic profile. Food Res. Int. 2016, 89, 422-431. [CrossRef]

16. Putnik, P.; Lorenzo, J.; Barba, F.; Roohinejad, S.; Režek Jambrak, A.; Granato, D.; Montesano, D.; Bursać Kovačević, D. Novel Food Processing and Extraction Technologies of High-Added Value Compounds from Plant Materials. Foods 2018, 7, 106. [CrossRef]

17. Chandrasekara, A.; Shahidi, F. Herbal beverages: Bioactive compounds and their role in disease risk reduction-A review. J. Tradit. Complement. Med. 2018, 8, 451-458. [CrossRef]

18. Caleja, C.; Finimundy, T.C.; Pereira, C.; Barros, L.; Calhelha, R.C.; Sokovic, M.; Ivanov, M.; Carvalho, A.M.; Rosa, E.; Ferreira, I.C.F.R. Challenges of traditional herbal teas: Plant infusions and their mixtures with bioactive properties. Food Funct. 2019, 10, 5939-5951. [CrossRef]

19. Pereira, C.; Barros, L.; Ferreira, I.C.F.R. A Comparison of the nutritional contribution of thirty-nine aromatic plants used as condiments and/or herbal infusions. Plant Foods Hum. Nutr. 2015, 70, 176-183. [CrossRef]

20. Ribeiro, A.; Caleja, C.; Barros, L.; Santos-Buelga, C.; Barreiro, M.F.; Ferreira, I.C.F.R. Caracterização do perfil fenólico do extrato aquoso e hidroetanólico de Rosmarinus officinalis L. Rev. Ciências Agrárias 2017, 40, S147-S150. [CrossRef]

21. Dias, M.I.; Barros, L.; Dueñas, M.; Alves, R.C.; Oliveira, M.B.P.P.; Santos-Buelga, C.; Ferreira, I.C.F.R. Nutritional and antioxidant contributions of Laurus nobilis L. leaves: Would be more suitable a wild or a cultivated sample? Food Chem. 2014, 156, 339-346. [CrossRef]

22. Marzouk, M.M.; Hussein, S.R.; Elkhateeb, A.; El-shabrawy, M.; Abdel-Hameed, E.S.S.; Kawashty, S.A. Comparative study of Mentha species growing wild in Egypt: LC-ESI-MS analysis and chemosystematic significance. J. Appl. Pharm. Sci. 2018, 8, 116-122. [CrossRef]

23. Barros, L.; Dueñas, M.; Carvalho, A.M.; Ferreira, I.C.F.R.; Santos-Buelga, C. Characterization of phenolic compounds in flowers of wild medicinal plants from Northeastern Portugal. Food Chem. Toxicol. 2012, 50, 1576-1582. [CrossRef] [PubMed]

24. Savarese, M.; De Marco, E.; Sacchi, R. Characterization of phenolic extracts from olives (Olea europaea cv. Pisciottana) by electrospray ionization mass spectrometry. Food Chem. 2007, 105, 761-770. [CrossRef]

25. Miguel, M.; Barros, L.; Pereira, C.; Calhelha, R.C.; Garcia, P.A.; Castro, M.Á.; Santos-Buelga, C.; Ferreira, I.C.F.R. Chemical characterization and bioactive properties of two aromatic plants:: Calendula officinalis L. (flowers) and Mentha cervina L. (leaves). Food Funct. 2016, 7, 2223-2232. [CrossRef]

26. Martins, N.; Barros, L.; Santos-Buelga, C.; Henriques, M.; Silva, S.; Ferreira, I.C. Decoction, infusion and hydroalcoholic extract of Origanum vulgare L.: different performances regarding bioactivity and phenolic compounds. Food Chem. 2014, 158, 73-80. [CrossRef]

27. Vieira, V.; Pereira, C.; Pires, T.C.S.P.; Calhelha, R.C.; Alves, M.J.; Ferreira, O.; Barros, L.; Ferreira, I.C.F.R. Phenolic profile, antioxidant and antibacterial properties of Juglans regia L. (walnut) leaves from the Northeast of Portugal. Ind. Crops Prod. 2019, 134, 347-355. [CrossRef]

28. Barros, L.; Duenas, M.; Dias, M.I.; Sousa, M.J.; Santos-Buelga, C.; Ferreira, I.C. Phenolic profiles of cultivated, in vitro cultured and commercial samples of Melissa officinalis L. infusions. Food Chem. 2013, 136, 1-8. [CrossRef]

29. Carocho, M.; Barros, L.; Barreira, J.C.M.; Calhelha, R.C.; Soković, M.; Fernández-Ruiz, V.; Buelga, C.S.; Morales, P.; Ferreira, I.C.F.R. Basil as functional and preserving ingredient in "serra da Estrela" cheese. Food Chem. 2016, 207, 51-59. [CrossRef]

30. Graça, V.C.; Barros, L.; Calhelha, R.C.; Dias, M.I.; Carvalho, A.M.; Santos-Buelga, C.; Ferreira, I.C.F.R.; Santos, P.F. Chemical characterization and bioactive properties of: Geranium molle L.: From the plant to the most active extract and its phytochemicals. Food Funct. 2016, 7. [CrossRef]

31. Martins, N.; Barros, L.; Santos-Buelga, C.; Silva, S.; Henriques, M.; Ferreira, I.C. Decoction, infusion and hydroalcoholic extract of cultivated thyme: antioxidant and antibacterial activities, and phenolic characterisation. Food Chem. 2015, 167, 131-137. [CrossRef]

32. Wang, M.; Li, J.; Ho, G.S.; Peng, X.; Ho, C.-T. Isolation and identification of antioxidative flavonoid glycosides from Thyme (Thymus vulgaris L.). J. Food Lipids 1998, 5, 313-321. [CrossRef] 
33. Ziani, B.E.C.; Heleno, S.A.; Bachari, K.; Dias, M.I.; Alves, M.J.; Barros, L.; Ferreira, I.C.F.R. Phenolic compounds characterization by LC-DAD- ESI/MSn and bioactive properties of Thymus algeriensis Boiss. \& Reut. and Ephedra alata Decne. Food Res. Int. 2019, 116, 312-319. [CrossRef] [PubMed]

34. Koffi, E.N.; Meudec, E.; Adjé, F.A.; Lozano, P.R.; Lozano, Y.F.; Bekro, Y.-A. Effect of reverse osmosis concentration coupled with drying processes on polyphenols and antioxidant activity obtained from Tectona grandis leaf aqueous extracts. J. Appl. Res. Med. Aromat. Plants 2015, 2, 54-59. [CrossRef]

35. Afonso, A.F.; Pereira, O.R.; Neto, R.T.; Silva, A.M.S.; Cardoso, S.M. Health-promoting effects of Thymus herba-barona, Thymus pseudolanuginosus, and Thymus caespititius decoctions. Int. J. Mol. Sci. 2017, 18, 1879. [CrossRef] [PubMed]

36. Wang, S.; Liu, L.; Wang, L.; Hu, Y.; Zhang, W.; Liu, R. Structural Characterization and Identification of Major Constituents in Jitai Tablets by High-Performance Liquid Chromatography/Diode-Array Detection Coupled with Electrospray Ionization Tandem Mass Spectrometry. Molecules 2012, 17, 10470-10493. [CrossRef]

37. Afonso, A.F.; Pereira, O.R.; Fernandes, Â.; Calhelha, R.C.; Silva, A.M.S.; Ferreira, I.C.F.R.; Cardoso, S.M. Phytochemical Composition and Bioactive Effects of Salvia africana, Salvia officinalis 'Icterina' and Salvia mexicana Aqueous Extracts. Molecules 2019, 24, 4327. [CrossRef] [PubMed]

38. Spínola, V.; Pinto, J.; Castilho, P.C. Identification and quantification of phenolic compounds of selected fruits from Madeira Island by HPLC-DAD-ESI-MSn and screening for their antioxidant activity. Food Chem. 2015, 173, 14-30. [CrossRef]

39. Rita, I.; Pereira, C.; Barros, L.; Santos-Buelga, C.; Ferreira, I.C. Mentha spicata L. infusions as sources of antioxidant phenolic compounds: emerging reserve lots with special harvest requirements. Food Funct. 2016, 7, 4188-4192. [CrossRef]

40. López-Angulo, G.; Montes-Avila, J.; Díaz-Camacho, S.P.; Vega-Aviña, R.; López-Valenzuela, J.Á.; Delgado-Vargas, F. Comparison of terpene and phenolic profles of three wild species of Echeveria (Crassulaceae). J. Appl. Bot. Food Qual. 2018, 91, 145-154. [CrossRef]

41. Goncalves, G.A.; Correa, R.C.G.; Barros, L.; Dias, M.I.; Calhelha, R.C.; Correa, V.G.; Bracht, A.; Peralta, R.M.; Ferreira, I. Effects of in vitro gastrointestinal digestion and colonic fermentation on a rosemary (Rosmarinus officinalis L) extract rich in rosmarinic acid. Food Chem. 2019, 271, 393-400. [CrossRef]

42. Caleja, C.; Barros, L.; Antonio, A.L.; Ciric, A.; Soković, M.; Oliveira, M.B.P.P.; Santos-Buelga, C.; Ferreira, I.C.F.R. Foeniculum vulgare Mill. As natural conservation enhancer and health promoter by incorporation in cottage cheese. J. Funct. Foods 2015, 12, 428-438. [CrossRef]

43. Caleja, C.; Ribeiro, A.; Barros, L.; Barreira, J.C.M.; Antonio, A.L.; Oliveira, M.B.P.P.; Barreiro, M.F.; Ferreira, I.C.F.R. Cottage cheeses functionalized with fennel and chamomile extracts: Comparative performance between free and microencapsulated forms. Food Chem. 2016, 199, 720-726. [CrossRef] [PubMed]

44. Viapiana, A.; Wesolowski, M. The Phenolic Contents and Antioxidant Activities of Infusions of Sambucus nigra L. Plant Foods Hum. Nutr. 2017, 72, 82-87. [CrossRef] [PubMed]

45. Caleja, C.; Barros, L.; Barreira, J.C.M.; Ciric, A.; Sokovic, M.; Calhelha, R.C.; Beatriz, M.; Oliveira, P.P.; Ferreira, I.C.F.R. Suitability of lemon balm (Melissa officinalis L.) extract rich in rosmarinic acid as a potential enhancer of functional properties in cupcakes. Food Chem. 2018, 250, 67-74. [CrossRef] [PubMed]

46. Soković, M.; Glamočlija, J.; Marin, P.D.; Brkić, D.; Griensven, L.J.L.D. van Antibacterial effects of the essential oils of commonly consumed medicinal herbs using an in vitro model. Molecules 2010, 15, 7532-7546. [CrossRef]

47. Pereira, E.; Antonio, A.L.; Barreira, J.C.M.; Barros, L.; Bento, A.; Ferreira, I.C.F.R. Gamma irradiation as a practical alternative to preserve the chemical and bioactive wholesomeness of widely used aromatic plants. Food Res. Int. 2015, 67, 338-348. [CrossRef]

48. AOAC. Official Methods of Analysis of AOAC International, 20th ed.; AOAC: Rockville, MD, USA, 2016.

49. Bessada, S.M.F.; Barreira, J.C.M.; Barros, L.; Ferreira, I.C.F.R.; Oliveira, M.B.P.P. Phenolic profile and antioxidant activity of Coleostephus myconis (L.) Rchb.f.: An underexploited and highly disseminated species. Ind. Crops Prod. 2016, 89, 45-51. [CrossRef]

50. Pinela, J.; Barros, L.; Duenas, M.; Carvalho, A.M.; Santos-Buelga, C.; Ferreira, I.C. Antioxidant activity, ascorbic acid, phenolic compounds and sugars of wild and commercial Tuberaria lignosa samples: Effects of drying and oral preparation methods. Food Chem. 2012, 135, 1028-1035. [CrossRef] 
51. Svobodova, B.; Barros, L.; Calhelha, R.C.; Heleno, S.; Alves, M.J.; Walcott, S.; Bittova, M.; Kuban, V.; Ferreira, I.C.F.R. Bioactive properties and phenolic profile of Momordica charantia L. medicinal plant growing wild in Trinidad and Tobago. Ind. Crops Prod. 2017, 95, 365-373. [CrossRef]

52. Soković, M.; Van Griensven, L.J.L.D. Antimicrobial activity of essential oils and their components against the three major pathogens of the cultivated button mushroom, Agaricus bisporus. Eur. J. Plant Pathol. 2006, 116, 211-224. [CrossRef]

Sample Availability: Samples are available in dry form the laboratory facilities of CIMO.

(C) 2020 by the authors. Licensee MDPI, Basel, Switzerland. This article is an open access article distributed under the terms and conditions of the Creative Commons Attribution (CC BY) license (http://creativecommons.org/licenses/by/4.0/). 